\title{
Functional traits of soil invertebrates as indicators for exposure to soil disturbance
}

\author{
Mickaël Hedde*, Folkert van Oort, Isabelle Lamy \\ INRA, UR 251 PESSAC, F78026 Versailles CEDEX, France
}

\section{A R T I C L E I N F O}

\section{Article history:}

Received 23 August 2011

Received in revised form

4 January 2012

Accepted 11 January 2012

\section{Keywords:}

Macrofauna

Exposure

Trace metal

Bioavailability

Soil organic matter

\begin{abstract}
A B S T R A C T
We tested a trait-based approach to link a soil disturbance to changes in invertebrate communities. Soils and macro-invertebrates were sampled in sandy soils contaminated by long-term wastewater irrigation, adding notably organic matter and trace metals (TM). We hypothesized that functional traits of invertebrates depict ways of exposure and that exposure routes relate to specific TM pools. Geophages and soft-body invertebrates were chosen to inform on exposure by ingestion or contact, respectively. Trait-based indices depicted more accurately effects of pollution than community density and diversity did. Exposure by ingestion had more deleterious effects than by contact. Both types of exposed invertebrates were influenced by TM, but geophages mainly responded to changes in soil organic matter contents. The trait-based approach requires to be applied in various conditions to uncorrelate specific TM impacts from those of other environmental factors.
\end{abstract}

(c) 2012 Elsevier Ltd. All rights reserved.

\section{Introduction}

Over the last decades growing evidence was given for negative effects of anthropogenic disturbances on the ability of soils to provide goods and services to human well-being (COM179 final, 2002). For a pertinent assessment of such negative effects, but also of restoration efficiency, executive authorities need reliable, accurate, and easy-to-use indicators. Ideally, such indicators must not solely be descriptive, but should also take account of the mechanisms by which the disturbance/restoration acts. Soil disturbance is currently assessed by different wide-used chemical and physicochemical soil parameters (Hooda, 2010), but measurement of the available concentrations is becoming a general tool in environmental research (ISO, 2008). Among disturbances, trace metal (TM) pollution represents a problem of major interest (van Gestel, 2008). Regarding TM, different chemical methods (isotopic dilution, neutral salt extraction or chelation with organic reagents) were proposed to define different TM pools (e.g. bioavailable, non-available, exchangeable, bound to organic matter) potentially impacting biota (Scheifler et al., 2003; van Gestel, 2008). The use of biological parameters has also been proposed. Ecotoxicological effects are currently measured by biomarkers, bioindicators or a combination of both (Brulle et al., 2010; Capowiez et al., 2010; van Gestel et al., 2009). However, these indicators depend on different factors like soil texture or microclimate which appear as confounding factors,

\footnotetext{
* Corresponding author.

E-mail address: mhedde@versailles.inra.fr (M. Hedde).
}

hampering the calibration of these tools to large scales (Hobbelen et al., 2006; Lukkari et al., 2004).

To overcome these drawbacks, functional trait-based concepts have emerged as a promising way for understanding the mechanisms that drive invertebrate responses to environmental disturbances (e.g. the habitat templet theory; Southwood, 1977). Functional traits of species are diversely defined but mainly concern species' properties that both affect individual fitness and govern species' impacts and responses to their environment (Violle et al., 2007). Trait-based approach is currently used in different fields of environmental studies, like ecology of plants (Lavorel and Garnier, 2002), stream invertebrates (Archaimbault et al., 2010) or fishes (Mims et al., 2010). Conversely, this approach was little applied on soil ecology, although functional trait profile has been stressed by several authors to be an important parameter for revealing invertebrate responses to contamination (Ribera et al., 2001; Skalski et al., 2010). Its development has been hampered by different factors such as the wide diversity of soil invertebrates and a lack of standardized sampling strategies, as well as low taxonomic expertise (Decaëns, 2010; Giller, 1996). Perhaps one of the most limiting factors may be the absence of a unified, shared database containing multiple information on a great number of taxa.

The present work aimed at demonstrating that functional traits of soil invertebrates provide new insights and better understanding of soil pollution effects than currently used indices of community structure. We applied a trait-based approach to depict disturbance impacts on soil invertebrate communities in a series of agricultural soils showing increasing amounts of organic matter and TM, resulting from long-term irrigation with urban wastewater. Another 
originality of our work lies in the mechanistic assumptions we made on relationships between soil pollution, chemical TM availabilities, the ways of exposure and the impacts on invertebrate communities. Hence, we hypothesized that the level of metal extractable with a neutral salt (ammonium nitrate) governs damage to soft-body invertebrates whereas more strongly bound metals, extractable with a complexing agent (DTPA), induce damage through ingestion.

\section{Materials and methods}

\subsection{Study site}

A series of soils selected from different irrigation plots at Pierrelaye (France, $49^{\circ} 01^{\prime} \mathrm{N} ; 2^{\circ} 10^{\prime} \mathrm{E}$ ) were sampled within a $\approx 1200$ ha-wide agricultural area. This area was used for more than one century for spreading of raw wastewater of the Paris urban region. The surface horizons of these soils accumulated large amounts of organic matter, dissolved salts (carbonates, phosphates) and metal pollutants, mainly zinc, lead, copper and cadmium (Lamy et al., 2006; van Oort et al., 2008). The soils, Orthic and Albic Luvisols (IUSS Working Group WRB, 2006), were sandy textured in the A and E horizons, and sandy-clay textured in the Bt horizon (van Oort et al., 2008). In the plow horizon of these soils, large amount of metal were recorded, up to about $1300 \mathrm{mg} \mathrm{Zn} \mathrm{kg}{ }^{-1}, 750 \mathrm{mg} \mathrm{Pb} \mathrm{kg}{ }^{-1}, 350 \mathrm{mg} \mathrm{Cu} \mathrm{kg}{ }^{-1}$ and $13 \mathrm{mg} \mathrm{Cd} \mathrm{kg}^{-1}$. Soil organic carbon contents in some soils were found to reach more than $125 \mathrm{~g} \mathrm{C} \mathrm{kg}^{-1}$ (Bourennane et al., 2006), conferring a remarkable dark color to the plow layer. This area offered good opportunities to test our trait-based approach considering the range of contamination levels and the homogeneous soil type.

Four irrigation plots were selected on the basis of previous extensive pedogeochemical survey in this area (Bourennane et al., 2006; Dère et al., 2006) (Table 1). A non-irrigated, unpolluted plot developed under similar geo-topographical conditions (van Oort et al., 2008), located about $0.5 \mathrm{~km}$ outside the wastewater irrigated area was included in our work as a reference soil. The five plots are hereafter called "unpolluted", "low", "low-intermediate", "intermediate-high" and high" according to their pollutant content. At the time of sampling, the reference and the contaminated plots were under arable land used with crop rotations, except for the "low" polluted plot which was under fallow land since about 10 years. All plots were located within an area of less than $3 \mathrm{~km}^{2}$.

\subsection{Soil sampling and analyses}

In each selected plot, four sampling zones of $0.5 \mathrm{~m}^{2}$ distant by $10 \mathrm{~m}$ were designed along a transect of $40 \mathrm{~m}$. At the corners of each sampling zone, $0-10 \mathrm{~cm}$ soil cores were taken and pooled. Soil $\mathrm{pH}$ determination was performed according to NF ISO 10390, total organic $\mathrm{C}$ and $\mathrm{N}$ according to NF ISO 10694 and total $\mathrm{Zn}, \mathrm{Pb}, \mathrm{Cu}$, and $\mathrm{Cd}$ according to NF X31-147 (tri-acid $\mathrm{HF}-\mathrm{HCl}-\mathrm{HNO}_{3}$ digestion). In addition, metal availability in soils was determined using two extracting reagents, 1) an organic chelating agent, the diethylenetriamine-pentaacetic acid (DTPA) and 2) a neutral salt, the ammonium nitrate $\left(\mathrm{NH}_{4} \mathrm{NO}_{3}\right)$. The $\mathrm{NH}_{4} \mathrm{NO}_{3}$ extraction was selected to estimate the easily exchangeable pool of metals (Prüess, 1992). Soil was homogeneized in a solution of $\mathrm{NH}_{4} \mathrm{NO}_{3} 1 \mathrm{~mol} \mathrm{l}^{-1}(1 / 2.5 \mathrm{~m} / \mathrm{v}$ ) (DIN 19730,1997). The DTPA extraction aims at quantifying exchangeable metals but also metals associated with organic matter and with $\mathrm{Mn}, \mathrm{Fe}$, and $\mathrm{Al}$ oxy-hydroxides (Baize and Tomasson, 2003; Dai et al., 2004). Extraction was done in triethanolamine- $\mathrm{CaCl}_{2}$-DTPA $(0.005 \mathrm{M})$ solution at $\mathrm{pH}=7.3$ (NF X 31-121). After extraction, total, $\mathrm{NH}_{4} \mathrm{NO}_{3}$ - and DTPA-extractable metal concentrations in solution were obtained from inductively coupled plasma mass spectroscopy. All soils analyses were made by the 'Laboratoire
d'Analyse des Sols' (INRA, Arras, France) applying standardized methods and quality assurance procedures.

\subsection{Invertebrate sampling and identification}

In the four sampling zones, two types of invertebrates were collected in March 2008, using a two-fold invertebrate sampling methodology. Sampling for active, surface-dwelling macro-invertebrates, was performed with pitfall-traps that consisted of $7 \mathrm{~cm}$ diameter plastic cups inserted in the soil with their top parallel to the soil surface. They were protected from rain by plastic cup lids, raised about $2 \mathrm{~cm}$ off the soil over the traps using support sticks. Traps were partially filled with vinegar as a preservative liquid. Their contents were collected after 1 week and preserved in $70^{\circ}$ alcohol for ulterior identification. Soil and litter dwelling macro-invertebrates were collected by hand sorting a $50 \times 50 \times 20 \mathrm{~cm}$ soil monolith in all selected sampling zones. Lumbricida, Isopoda, Chilopoda and Coleoptera (carabidae, scarabeidae, histeridae) were identified to the species level according to several identification keys (Bouché, 1972; Demange, 1981; Hopkins, 1991; Jeannel, 1941, 1942; Paulian, 1941). Other invertebrates were identified as precisely as possible.

\subsection{Indices of invertebrate community structure}

We calculated three indices of community structure to estimate invertebrate density, activity and diversity. Hand sorting permitted evaluation of the density of soil and litter dwelling macro-invertebrates (expressed as individuals per square meter, ind. $\mathrm{m}^{-2}$ ). Pitfall-trapping informed on the surface activity of macro-invertebrates (expressed as ind. $\operatorname{trap}^{-1}$ ). We also calculated the relative abundance of each taxa in both hand-sorted and pitfall-trapped invertebrates datasets, and combined them thereafter. Then, we calculated the taxonomic diversity, expressed as Observable Taxonomic Units (OTU) per sampling point.

\subsection{Calculation of functional trait profiles}

A general characteristic of ecological knowledge of species is that it has a very diverse structure and semantic. Consequently, ecologists obtain quantitative or qualitative information from various sources (aggregated data, books, literature, own descriptive or experimental works, scattered personal information, etc). As a result there is need for homogenization to inform functional trait profiles. The fuzzy coding method has been developed by Chevenet et al. (1994) and is now widely used in aquatic ecology. This method attempts to synthetize and code the diverse information available on functional traits. Because of the heterogeneity of organisms within and between species and the missing data, it was suggested to code by reducing continuous variables into a limited number of subsets with specific characteristics.

We specifically determined the integument sclerotization and the food of invertebrates, assuming that these functional traits are related to pollutant exposure by contact or by ingestion, respectively. Integument sclerotization was deduced from observation and assigned to 2 categories (unsclerotized or sclerotized). Information on food of taxa was obtained from about 200 data sources (Supplementary material) and attributed to 7 categories (roots, vegetative aerial tissues of plants, fruit or seed, dead animals, living animals, plant detritus and soil). The information obtained from each source was coded by an affinity score ranging from 0 to 3 (from no to very high affinity of the taxon to a trait category, respectively). Subsequently, affinities were summed to build the trait profile (e.g. the distribution of affinity within category of a trait). Trait profiles were standardized so that their sum for a given taxon and a given trait equaled $100 \%$. Scores 'zero' for all categories of a trait signify that information is not currently available. In that case, taxa take the mean trait profile of all other taxa in subsequent trait analyses (i.e. such a taxon does not contribute to patterns). Finally, we calculated the mean trait category affinity per community

Table 1

Mean values of selected physico-chemical data of the studied soils. Brackets contain standard error of the mean. Different letters indicate mean differences $(p<0.05)$.

\begin{tabular}{|c|c|c|c|c|c|c|c|c|c|}
\hline & \multirow[t]{2}{*}{$\mathrm{pH}$} & \multirow[t]{2}{*}{$\operatorname{CEC}\left(\mathrm{cmol}^{+} \mathrm{kg}^{-1}\right)$} & \multirow[t]{2}{*}{$\mathrm{C}$ org $\left(\mathrm{g} \mathrm{kg}^{-1}\right)$} & \multirow[t]{2}{*}{$\mathrm{N}$ tot $\left(\mathrm{g} \mathrm{kg}^{-1}\right)$} & \multirow[t]{2}{*}{$\mathrm{C} / \mathrm{N}$} & $\mathrm{Cu}$ & $\mathrm{Pb}$ & $\mathrm{Zn}$ & $\mathrm{Cd}$ \\
\hline & & & & & & \multicolumn{4}{|c|}{ Total $\left(\mathrm{mg} \mathrm{kg}^{-1}\right)$} \\
\hline unpolluted & $8.2(0.0) a$ & $4.9(0.0) \mathrm{c}$ & $10.9(0.0) \mathrm{c}$ & $0.9(0.0) \mathrm{c}$ & $13(0) b$ & $11(0) d$ & $30(0) c$ & $43(1) d$ & $0.3(0) \mathrm{c}$ \\
\hline low & $7.8(0.1) \mathrm{b}$ & $6.5(0.2) b$ & 33.7 (4.9) b & $1.3(0.1) b c$ & $25(2) a$ & 81 (15) cd & $181(24) b$ & $282(53) c$ & $1.6(0.3) \mathrm{b}$ \\
\hline low-intermediate & $7.4(0.1) b c$ & $6.6(0.2) b$ & $18.0(5.7) \mathrm{c}$ & $1.3(0.1) b c$ & $14(3) b$ & 115 (18) bc & 173 (37) b & 421 (59) bc & $2.3(0.3) a b$ \\
\hline intermediate-high & $7.4(0.1) b c$ & $9.4(0.6) a b$ & $57.1(4.9)$ a & $2.4(0.1) \mathrm{ab}$ & $24(3) \mathrm{a}$ & $167(16) \mathrm{ab}$ & 379 (33) a & 580 (51) ab & $2.5(0.3) a b$ \\
\hline \multirow[t]{3}{*}{ high } & $7.4(0.0) \mathrm{c}$ & $11.2(1.6) \mathrm{a}$ & $64.9(0.1) \mathrm{a}$ & $2.8(0.0) a b$ & $23(1) \mathrm{a}$ & $233(3) \mathrm{a}$ & $401(12) a$ & 707 (3) ab & $3.0(0.1) \mathrm{a}$ \\
\hline & $\mathrm{Cu}$ & $\mathrm{Pb}$ & $\mathrm{Zn}$ & $\mathrm{Cd}$ & $\mathrm{Cu}$ & $\mathrm{Pb}$ & $\mathrm{Zn}$ & $\mathrm{Cd}$ & \\
\hline & \multicolumn{4}{|c|}{$\mathrm{NH}_{4}-\mathrm{NO}_{3}$ extracted $\left(\mu \mathrm{g} \mathrm{kg}^{-1}\right)$} & \multicolumn{5}{|c|}{ DTPA complexed $\left(\mathrm{mg} \mathrm{kg}^{-1}\right)$} \\
\hline unpolluted & $82(0) c$ & $5(0) c$ & $19(0) c$ & $4(0) c$ & $2(0) c$ & $5(0) c$ & $4(0) c$ & $0.1(0.0) \mathrm{b}$ & \\
\hline low & $459(70) \mathrm{b}$ & $17(2) \mathrm{a}$ & $486(106) b$ & $15(2) b$ & $15(6) b$ & $21(7) \mathrm{b}$ & $50(22) \mathrm{b}$ & $0.6(0.2) \mathrm{b}$ & \\
\hline low-intermediate & $865(90)$ a & $11(3) b$ & $1117(122) \mathrm{a}$ & $28(3) \mathrm{a}$ & 40 (7) a & $29(8) b$ & $101(24) \mathrm{a}$ & $1.1(0.3) a b$ & \\
\hline intermediate-high & $660(80)$ ab & $19(3) \mathrm{a}$ & 917 (104) a & $13(2) b$ & $35(6) \mathrm{a}$ & $43(7) \mathrm{a}$ & $107(20) \mathrm{a}$ & $0.9(0.2) \mathrm{ab}$ & \\
\hline high & 793 (18) a & $18(1) \mathrm{a}$ & 1297 (11) a & $16(0) \mathrm{b}$ & 48 (1) a & $43(1) a$ & $139(2) \mathrm{a}$ & $1.2(0.0) \mathrm{ab}$ & \\
\hline
\end{tabular}


$(\mathrm{mT})$, as the average of category affinity values weighted by the relative abundance of species carrying each affinity (Garnier et al., 2004) with the following equation:

$\mathrm{mT}=\sum_{i=1} p_{i} x_{i}$

where $x_{\mathrm{i}}$ is the trait category affinity of the $\mathrm{i}$-th species, and $p_{\mathrm{i}}$ its relative abundance.

\subsection{Statistical analyses}

Mean differences in structural indices and proportion in trait categories within communities were tested using Tukey (HSD) post-hoc test after ANOVA. Prior to analysis, data normality and homoscedasticity were tested using Wilk-Shapiro and Bartlett tests. A logarithmic transformation was used to homogenize variances if necessary. Linear models of soft-body and geophage proportions with soil parameters as independent variables were tested. All statistical analyses were performed at the significant level of $\alpha=0.05$, using the 'base' library for R Software (R Development Core Team 2011)

\section{Results and discussion}

\subsection{Soil pollution gradient}

Soil texture, an intrinsic pedogenetic characteristic of the soils showed little variation, with clay contents ranging from 7.4 to $10.5 \%$ and total sand contents from 74 to $84 \%$. Characteristic physicochemical soil data are presented in Table 1 . The soil pH was consistently higher in the limed unpolluted top soil compared to the contaminated surface horizons, ascribed to the buffering action of large rates of organic matter of urban origin and despite the presence of $2-4 \%$ of secondary carbonates added by wastewater irrigation (van Oort et al., 2008).

The soil organic $C$ content ranged from 11.0 to $64.9 \mathrm{~g} \mathrm{~kg}^{-1}$, i.e. a six-fold variation. In Pierrelaye topsoil, the filtering of large amounts of wastewater led to the accumulation of exogenous (fine, amorphous) organic matter distributed as coatings around the quartz grains explaining the outstanding dark color of the surface horizon (van Oort et al., 2008). The $\mathrm{C} / \mathrm{N}$ ratios of irrigated soils were comparable $(\approx 23-25$, except for the low-intermediate polluted plot), about two-fold higher than for the unpolluted reference soil.

According to the plot selection, the total TM concentrations showed a fairly regular increase, with maximum values for the ratio between the uncontaminated and the most contaminated soil of about $1: 10$ for $\mathrm{Cd}, 1: 12$ for $\mathrm{Pb}, 1: 16$ for $\mathrm{Zn}$, and 1:20 for $\mathrm{Cu}$ (Table 1). The concentration of $\mathrm{NH}_{4} \mathrm{NO}_{3}$-extracted metals increased significantly in irrigated plots when compared with unpolluted one. For $\mathrm{Zn}$ and $\mathrm{Cu}$, the gradient was similar to the total content one. However, the low-intermediate polluted plot presented significant lower $\mathrm{Pb}$, and higher $\mathrm{Cd}$ values than those of other irrigated plots. The concentration of DTPA-extractable metals increased with increasing total metal contents, the ratio between the uncontaminated and the most contaminated soil was about $1: 12$ for $\mathrm{Cd}, 1: 9$ for $\mathrm{Pb}, 1: 39$ for $\mathrm{Zn}$, and 1:33 for $\mathrm{Cu}$. In irrigated plots, DTPA-extracted metals represented $18-24 \%, 11-17 \%, 18-35 \%$ and $36-48 \%$ of total concentration, for $\mathrm{Zn}, \mathrm{Pb}, \mathrm{Cu}$ and $\mathrm{Cd}$ respectively. These proportions were within the ranges found in literature, rather low for $\mathrm{Zn}$ and $\mathrm{Pb}$ and high for $\mathrm{Cu}$ and $\mathrm{Cd}$ (Dai et al., 2004; Kashem et al., 2007).

Physico-chemical parameters reflected a strong influence of the long-term irrigation practices. Metal pollutant concentrations were shown strongly correlated with organic C, due to their concomitant input by wastewater irrigation (Bourennane et al., 2006). Such co-variation of multiple parameters along soil pollution gradient is common in many field studies on pollution. Delineating specific effects of multiple pollution is usually a challenging task, since changes in relative proportion of pollutants, their speciation and/or their bioavailability frequently occur concomitantly with soil characteristics (van Gestel, 2008).

\subsection{Impacts of soil contamination on the structure of invertebrate communities}

A total of 586 individuals were collected, 428 by pitfall-trapping and 158 by hand sorting. Forty-three taxa were identified, depicted in Table 2 . About $85 \%$ of trapped invertebrates belonged to four taxonomic groups, i.e. Araneae (41\%), Carabidae (24\%), Staphylinidae (10\%) and Julidae (10\%). Similarly, four groups represented about $90 \%$ of hand-sorted invertebrates, i.e. Lumbricidae (63\%), Carabidae (6\%), Julidae (5\%) and various insect larva (e.g. campodeiform, melolonthoïde, eruciform, elateriform; $20 \%$ ). Results showed a decreasing abundance as soil pollution increased (Fig. 1A). The unpolluted plot hosted 80 ind. $\mathrm{m}^{-2}$. A density of 53 ind. $\mathrm{m}^{-2}$ was determined in the low polluted plot whereas the three most contaminated plots contained much smaller values, ranging from 1 to 27 ind. $\mathrm{m}^{-2}$. By contrast, the activity of invertebrates at the surface was only slightly affected by soil pollution (Fig. 1B). Only the intermediate-high polluted plot differed significantly from the others. A mean value of 52 ind. $\operatorname{trap}^{-1}$ was observed while, in average, less than 25 individuals were trapped in the four other plots. Regarding the overall diversity of invertebrates (Fig. 1C), the intermediate-high polluted plot hosted the most diverse assemblages (15.0 OTU). Recorded value was about 2.2-fold greater than the lowest value (lowintermediate pollution, 7 OTU), but did not significantly differ from the other plots (Fig. 1C).

Consequently, in these field conditions, the activity or taxonomic diversity of soil invertebrates were not revealed as suitable indicators for the impacts of soil disturbance by wastewater pollution. In addition, the abundance of invertebrates was found only partially linked to the gradient in soil pollution. These findings were found consistent with a large part of literature. Many authors have stressed the lack of relationships between soil TM contamination and parameters of community structure they measured (Lock et al., 2001; Pizl et al., 2009; Tischer, 2008; van Gestel et al., 2009). Such absence of correlation may be ascribed to the wide range of environmental characteristics covered by the respective studies (Hobbelen et al., 2006; Lukkari et al., 2004) or to substitution of sensitive by tolerant species without changes neither in abundance nor in diversity (Eeva et al., 2004). In most studies on this topic, taxonomic groups were often investigated independently one to each other e.g. earthworms (Spurgeon and Hopkin, 1999), millipedes or isopoda (Grelle et al., 2000), ground beetles (Lock et al., 2001) or ants (Grzes, 2009). Such a group-specific approach limits the study of the range of biological strategies that can be developed by soil invertebrates in response to contamination. Yet, significant relationships between parameters of invertebrate communities and soil metal pollution were reported by some authors, but in fact restricted to two main cases. The first case of good correlation was recorded when the range of contamination of the study situations was very large, i.e. the most contaminated site exhibiting values more than 100 -fold higher than those recorded in the reference or the less contaminated one (Grelle et al., 2000; Nahmani and Lavelle, 2002; Spurgeon and Hopkin, 1999). The maximum gradient of pollution then corresponded to extreme soil contaminations, i.e. metalliferous grassland hosting a very low number, if any, of soil invertebrates. The second case of good correlation arising from literature concerns studies conducted in boreal coniferous forest environments, also reporting indices of community structure being influenced by soil metal contamination (Eeva et al., 2004; Haimi and Mätäsniemi, 2002; Koponen and Koneva, 2005). The low diverse communities characterizing these soils are probably more impacted via a greater exposure to pollutants, since trace metals are generally more solubilized in acid soil conditions. 
Table 2

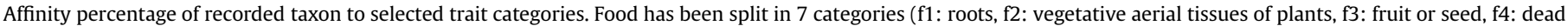
animals; f5: living animals; f6: plant detritus; f7: soil), the body sclerotization in two categories (b1 soft-body; b2 hard body).

\begin{tabular}{|c|c|c|c|c|c|c|c|c|c|c|c|c|}
\hline Phyllum & Classes & Order & Taxon & f1 & $\mathrm{f} 2$ & f3 & $\mathrm{f} 4$ & f5 & f6 & f7 & b1 & b2 \\
\hline Arthopoda & Chelicerata & Arachnida & Araneae & 0 & 0 & 0 & 0 & 100 & 0 & 0 & 50 & 50 \\
\hline Arthopoda & Chelicerata & Arachnida & Opiliones & 0 & 0 & 0 & 0 & 100 & 0 & 0 & 50 & 50 \\
\hline Arthopoda & Diplopoda & Diplopoda & Julidae & 0 & 0 & 0 & 0 & 0 & 95 & 5 & 0 & 100 \\
\hline Arthopoda & Diplopoda & Diplopoda & Polydesmidae & 0 & 0 & 0 & 0 & 0 & 95 & 5 & 0 & 100 \\
\hline Arthopoda & Malacostracea & Isopoda & Porcellio scaber & 0 & 0 & 0 & 0 & 0 & 95 & 5 & 0 & 100 \\
\hline Arthopoda & Insecta & Coleoptera Adephaga & Amara aenea & 0 & 44 & 41 & 0 & 15 & 0 & 0 & 0 & 100 \\
\hline Arthopoda & Insecta & Coleoptera Adephaga & Amara eurynota & 0 & 26 & 62 & 0 & 12 & 0 & 0 & 0 & 100 \\
\hline Arthopoda & Insecta & Coleoptera Adephaga & Amara familiaris & 0 & 58 & 15 & 0 & 27 & 0 & 0 & 0 & 100 \\
\hline Arthopoda & Insecta & Coleoptera Adephaga & Amara sp & 0 & 75 & 0 & 0 & 25 & 0 & 0 & 0 & 100 \\
\hline Arthopoda & Insecta & Coleoptera Adephaga & Asaphidion stierlini & 0 & 100 & 0 & 0 & 0 & 0 & 0 & 0 & 100 \\
\hline Arthopoda & Insecta & Coleoptera Adephaga & Harpalus affinis & 0 & 32 & 48 & 0 & 20 & 0 & 0 & 0 & 100 \\
\hline Arthopoda & Insecta & Coleoptera Adephaga & Harpalus distinguendus & 0 & 0 & 50 & 0 & 50 & 0 & 0 & 0 & 100 \\
\hline Arthopoda & Insecta & Coleoptera Adephaga & Harpalus froelichi & 0 & 32 & 68 & 0 & 0 & 0 & 0 & 0 & 100 \\
\hline Arthopoda & Insecta & Coleoptera Adephaga & Harpalus tardus & 0 & 100 & 0 & 0 & 0 & 0 & 0 & 0 & 100 \\
\hline Arthopoda & Insecta & Coleoptera Adephaga & Leistus sp & 0 & 100 & 0 & 0 & 0 & 0 & 0 & 0 & 100 \\
\hline Arthopoda & Insecta & Coleoptera Adephaga & Loricera pilicornis & 0 & 6 & 0 & 0 & 94 & 0 & 0 & 0 & 100 \\
\hline Arthopoda & Insecta & Coleoptera Adephaga & Metallina lampros & 0 & 28 & 17 & 6 & 50 & 0 & 0 & 0 & 100 \\
\hline Arthopoda & Insecta & Coleoptera Adephaga & Nebria brevicollis & 0 & 0 & 11 & 0 & 89 & 0 & 0 & 0 & 100 \\
\hline Arthopoda & Insecta & Coleoptera Adephaga & Notiophilus substriatus & 0 & 14 & 0 & 0 & 86 & 0 & 0 & 0 & 100 \\
\hline Arthopoda & Insecta & Coleoptera Adephaga & Poecilus cupreus & 0 & 28 & 16 & 0 & 57 & 0 & 0 & 0 & 100 \\
\hline Arthopoda & Insecta & Coleoptera Adephaga & Poecilus lepidus & 0 & 0 & 50 & 0 & 50 & 0 & 0 & 0 & 100 \\
\hline Arthopoda & Insecta & Coleoptera Adephaga & Pseudoophonus rufipes & 0 & 23 & 8 & 0 & 69 & 0 & 0 & 0 & 100 \\
\hline Arthopoda & Insecta & Coleoptera Adephaga & Pterostichus niger & 14 & 0 & 14 & 0 & 71 & 0 & 0 & 0 & 100 \\
\hline Arthopoda & Insecta & Coleoptera Polyphaga & Curculionidae & 0 & 100 & 0 & 0 & 0 & 0 & 0 & 0 & 100 \\
\hline Arthopoda & Insecta & Coleoptera Polyphaga & Histeridae & 0 & 0 & 0 & 0 & 100 & 0 & 0 & 0 & 100 \\
\hline Arthopoda & Insecta & Coleoptera Polyphaga & Sylphidae & 0 & 0 & 0 & 0 & 100 & 0 & 0 & 0 & 100 \\
\hline Arthopoda & Insecta & Coleoptera Polyphaga & Staphylinidae & 0 & 0 & 0 & 0 & 0 & 0 & 0 & 0 & 100 \\
\hline Arthopoda & Insecta & Coleoptera Polyphaga & Other polyphaga & 0 & 0 & 0 & 0 & 0 & 0 & 0 & 0 & 100 \\
\hline Arthopoda & Insecta & Coleoptera Polyphaga & Campodeiform larvae & 0 & 0 & 0 & 0 & 100 & 0 & 0 & 75 & 25 \\
\hline Arthopoda & Insecta & Coleoptera Polyphaga & Elateriform larvae & 50 & 0 & 0 & 0 & 50 & 0 & 0 & 0 & 100 \\
\hline Arthopoda & Insecta & Coleoptera Polyphaga & Melolonthoïd larvae & 95 & 0 & 0 & 0 & 0 & 0 & 5 & 100 & 0 \\
\hline Arthopoda & Insecta & Diptera & Other larvae & 0 & 0 & 0 & 0 & 0 & 0 & 0 & 100 & 0 \\
\hline Arthopoda & Insecta & Diptera & Tipulidae larvae & 50 & 25 & 0 & 0 & 0 & 25 & 0 & 100 & 0 \\
\hline Arthopoda & Insecta & Hemiptera & Hemiptera & 0 & 50 & 0 & 0 & 50 & 0 & 0 & 0 & 100 \\
\hline Arthopoda & Insecta & Heteroptera & Heteroptera & 0 & 100 & 0 & 0 & 0 & 0 & 0 & 0 & 100 \\
\hline Arthopoda & Insecta & Hymenoptera & Hymenoptera & 0 & 0 & 0 & 0 & 0 & 0 & 0 & 0 & 100 \\
\hline Arthopoda & Insecta & Lepidoptera & Larvae & 0 & 100 & 0 & 0 & 0 & 0 & 0 & 100 & 0 \\
\hline Mollusca & Gastropoda & Pulmonata & Agriolimacidae & 0 & 100 & 0 & 0 & 0 & 0 & 0 & 100 & 0 \\
\hline Mollusca & Gastropoda & Pulmonata & Arionidae & 0 & 100 & 0 & 0 & 0 & 0 & 0 & 100 & 0 \\
\hline Annelida & Oligochaeta & Opistophora & Allolobophora chlorotica & 0 & 0 & 0 & 0 & 0 & 0 & 100 & 100 & 0 \\
\hline Annelida & Oligochaeta & Opistophora & Aporrectodea caliginosa & 0 & 0 & 0 & 0 & 0 & 0 & 100 & 100 & 0 \\
\hline Annelida & Oligochaeta & Opistophora & Aporrectodea icterica & 0 & 0 & 0 & 0 & 0 & 0 & 100 & 100 & 0 \\
\hline Annelida & Oligochaeta & Opistophora & Lumbricus castaneus & 0 & 0 & 0 & 0 & 0 & 90 & 10 & 100 & 0 \\
\hline
\end{tabular}

\subsection{Functional traits: a footprint of soil contamination impacting invertebrate communities}

Results showed a decrease in the proportion of geophages from $49 \%$ (unpolluted) to $29 \%$ (low polluted) and less than $6 \%$ in the three most contaminated plots (Fig. 2). The soft-body proportion decreased regularly. In the unpolluted plots, the proportion was $60 \%$ and decreased from $49 \%$ to $29 \%$ (low and high polluted plots, respectively). This type of expression of the results demonstrated a clear decrease of the proportion of the most exposed invertebrates with increasing contamination. In the present case, effects $(-20 \%)$ on geophages were encountered even at low pollution level. Conversely, significant effects on soft-body proportion were recorded from low-intermediate plot $(-15 \%)$. The different trends of relationships between geophagous or soft-body proportions and pollution level suggest that exposure by ingestion was more harmful than by contact. Such approach associates information on species distribution to their biological characteristics providing a biological trait profile of communities. Trait-based indices complement structural measures using taxonomic composition by providing indirect information on soil ecological functioning.

Since geophage or soft-body proportions were negatively impacted by pollution level, a next step was to test whether observed responses can be attributed to specific TM pools. Geophage proportions were significantly influenced by CEC, organic $\mathrm{C}$, total $\mathrm{N}$, total TM, $\mathrm{NH}_{4} \mathrm{NO}_{3}$-extracted $\mathrm{Pb}$ and DTPA-extracted TM contents (Table 3 ). Linear models using CEC, total $\mathrm{N}$ and organic C content as independent variables expressed $49 \%, 47 \%$ and $36 \%$ of variance, respectively. Analyses of covariance showed that adding any TM variable as co-variate in models to pedological parameters did not improve the expressed variance. Thus, we did not verify the hypothesis that more strongly bound metals, rather than total contents, would provide a good indicator of TM damage through ingestion. Nevertheless, we can state that $\mathrm{NH}_{4} \mathrm{NO}_{3}-$ extracted TM had no influence on geophage proportions, except for lead. Alternatively, the decline in geophage proportion illustrated changes in soil organic matter (content and reactivity) added by long-term wastewater irrigation. As discussed above, the filtering of large amounts of wastewater in these soils led to the accumulation of exogenous, amorphous organic matter (van Oort et al., 2008). Consequently, relationships with CEC, organic $\mathrm{C}$ and total $\mathrm{N}$ contents reflect an effect of variable amounts of soil organic matter, with likely low palatability for soil invertebrates. The disappearance or the significant decrease in geophages likely induces major consequences from a point of view of soil behavior, since these animals are primarily involved in soil dynamics 

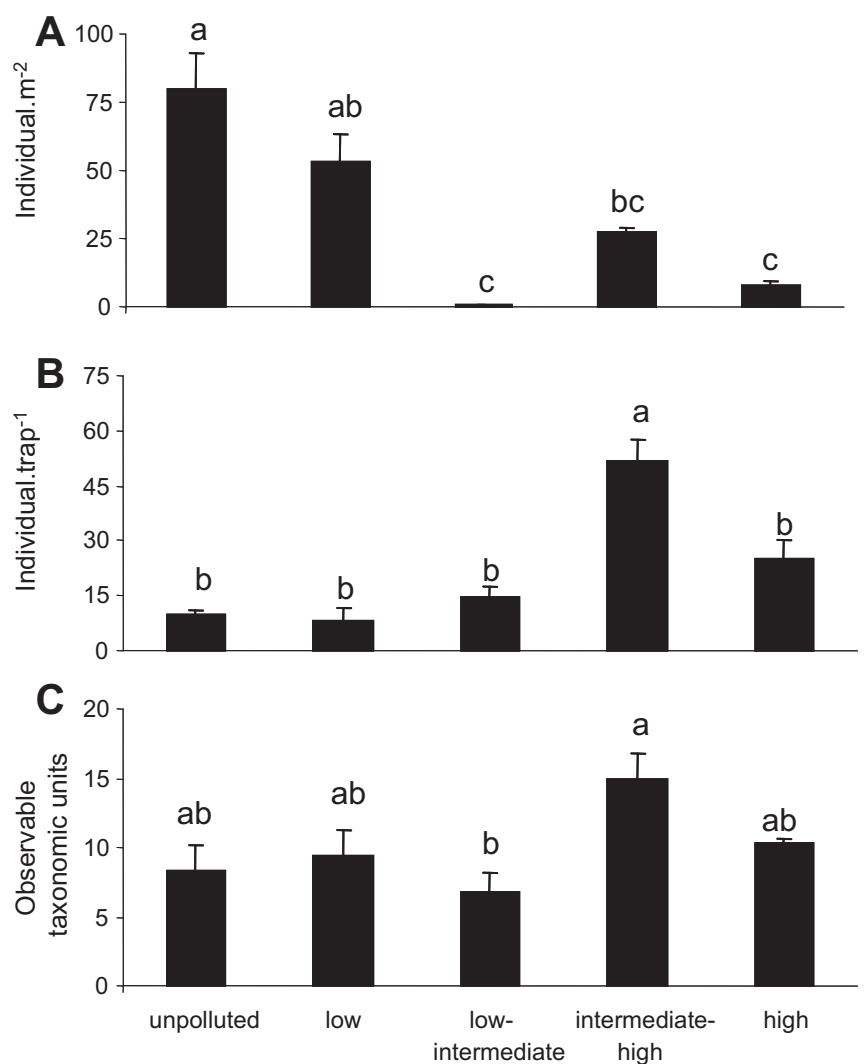

Fig. 1. Relationships (mean $\pm \mathrm{SEM} ; n=4$ ) between indices of macro-invertebrate community structure and soil contamination level in agricultural plots of the Pierrelaye wastewater irrigation area (France). A, density of soil and litter dwelling invertebrates; B, abundance-activity of invertebrates at soil surface; $C$ overall diversity of invertebrates. Different letters indicated statistical differences $(p<0.05)$.

such as nutrient turn-over and soil aggregation (Lavelle and Spain, 2001).

On the other hand, soft-body proportions were significantly influenced by soil $\mathrm{pH}, \mathrm{CEC}, \mathrm{C} / \mathrm{N}$ ratio, total $\mathrm{N}$, total TM, DTPAextracted $\mathrm{TM}$ and $\mathrm{NH}_{4} \mathrm{NO}_{3}$-extracted TM (except for $\mathrm{Pb}$ ) contents (Table 3). F-values indicated that models built with $\mathrm{Zn}$ extracted by $\mathrm{NH}_{4} \mathrm{NO}_{3}$ and $\mathrm{Cd}$ and $\mathrm{Cu}$ extracted by DTPA, as independent variables, expressed a great part of variance. Additionally, analyses of covariance showed that adding any pedological variable as co-variate in the models involving either DTPA-extracted, $\mathrm{NH}_{4} \mathrm{NO}_{3}$-extracted (but $\mathrm{Pb}$ ) or total $\mathrm{Zn}$ and $\mathrm{Cd}$ contents, did not improve the expressed

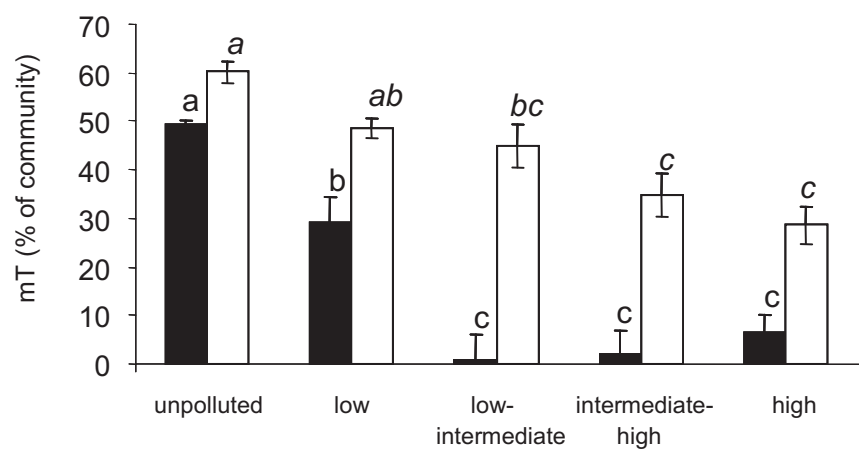

Fig. 2. Relationships (mean \pm SEM; $n=4$ ) between mean proportion of soft-body (open bars) and geophage (black bars) individuals in macro-invertebrate community $(\mathrm{mT})$ and soil contamination level in agricultural plots of the Pierrelaye wastewater irrigation area (France). For each data series, different letters indicated statistical differences $(p<0.05)$.
Table 3

Parameters of linear models between mean trait category affinities (geophage and soft-body $\mathrm{mT}$ ) and soil parameters. All slopes were negative. Bold numbers indicated significant linear model.

\begin{tabular}{|c|c|c|c|c|c|}
\hline & & \multicolumn{2}{|c|}{ Geophage mT } & \multicolumn{2}{|c|}{ Soft-body mT } \\
\hline & & $F$ value & $p$ value & $F$ value & $p$ value \\
\hline \multirow[t]{5}{*}{ Pedological parameters } & $\mathrm{pH}$ & 3.06 & 0.097 & 12.41 & 0.002 \\
\hline & CEC & 17.49 & 0.001 & 4.58 & 0.046 \\
\hline & C org & 10.19 & 0.005 & 3.02 & 0.099 \\
\hline & $\mathrm{N}$ total & 16.08 & 0.001 & 6.51 & 0.020 \\
\hline & $\mathrm{C} / \mathrm{N}$ & 0.46 & 0.505 & 5.07 & 0.037 \\
\hline \multirow[t]{4}{*}{ Total metal content } & $\mathrm{Cu}$ & 6.34 & 0.021 & 5.87 & 0.026 \\
\hline & $\mathrm{Pb}$ & 8.16 & 0.010 & 5.54 & 0.030 \\
\hline & $\mathrm{Zn}$ & 9.90 & 0.006 & 11.98 & 0.003 \\
\hline & $\mathrm{Cd}$ & 7.81 & 0.012 & 14.96 & 0.001 \\
\hline \multirow[t]{4}{*}{$\mathrm{NH}_{4} \mathrm{NO}_{3}$-extracted metal content } & $\mathrm{Cu}$ & 2.82 & 0.110 & 11.95 & 0.003 \\
\hline & $\mathrm{Pb}$ & 5.92 & 0.026 & 2.29 & 0.148 \\
\hline & $\mathrm{Zn}$ & 4.07 & 0.059 & 25.09 & $<0.001$ \\
\hline & $\mathrm{Cd}$ & 0.49 & 0.493 & 9.71 & 0.006 \\
\hline \multirow[t]{4}{*}{ DTPA-extracted metal content } & $\mathrm{Cu}$ & 8.13 & 0.011 & 18.51 & $<0.001$ \\
\hline & $\mathrm{Pb}$ & 7.58 & 0.013 & 9.15 & 0.007 \\
\hline & $\mathrm{Zn}$ & 5.17 & 0.035 & 12.33 & 0.002 \\
\hline & $\mathrm{Cd}$ & 7.98 & 0.011 & 24.18 & $<0.001$ \\
\hline
\end{tabular}

variance. For total $\mathrm{Cu}$ and $\mathrm{Pb}$ contents, a linear model involving $\mathrm{pH}$ ameliorated the part of variance expressed but did not differed from the model with $\mathrm{pH}$ alone. TM pollution thus appeared as the main factor explaining soft-body animal proportion in macro-invertebrate communities. Nevertheless, interactions with $\mathrm{pH}$ cannot be totally excluded. Again, in our conditions the hypothesis of predominant effect of weakly bound TM on soft-body invertebrates was not verified. While linear model with $\mathrm{NH}_{4} \mathrm{NO}_{3}$-extracted $\mathrm{Zn}$ content explained $58 \%$ of soft-body proportion variance, DTPA-extracted Cd and $\mathrm{Cu}$ content also modeled $57 \%$ and $41 \%$ of it.

In a more general context, and as observed for studies on soil invertebrate community structure, most of the literature on trait-based approach using soil fauna focused on only one single taxonomic group, e.g. springtails (Makkonen et al., 2011), carabids (Ribera et al., 2001), or earthworms (Decaëns et al., 2008). Studying the entire community, and not taxonomically a priori defined groups, permits to encompass most of biological strategies and to infer the mechanisms by which soil contamination alters soil communities. However, it can be argued that taxa allocation for food trait in the initial phase of the analysis is quite limited and reflects the influence of phylogeny on soil invertebrate biology. We assume however that it also results from a failure to the description of soil invertebrate feeding habits in current literature. For instance, the ingestion of soil particles is particularly well-documented for the different ecomorphological groups of earthworms (epigeic, anecic and endogeic), but many soil- and surface-dwelling macroarthropods inevitably take up more or less important amounts of soil (Wolters, 2000), either by hasard or to achieve their requirements in some mineral nutrients like calcium or magnesium. Unfortunately, information on soil ingestion by rhizo- and saprophages are scarce, and very little quantitative data is available. Literature on woodlice (Vijver et al., 2006), millipedes (Crawford, 1976; Kaneko, 1999; Tajovsky, 1992), scarabeiform larvae (McQuillan and Webb, 1994) suggested zero to low proportion of soil in animal food, but high proportions have also been recorded (26-43\% for millipedes in Dangerfield, 1993). Consequently, in the absence of large and reliable datasets on 'neglected groups of decomposers' (Wolters, 2001), we attributed a $5 \%$ proportion of soil in diet for woodlice, millipedes and scarabeiform larvae. Isotope techniques seem to be particularly useful to overcome this drawback (Curry and Schmidt, 2007).

Finally, to be generally applicable, soil invertebrate trait-based approaches require to interface conceptual, and respective methodological improvements, from soil chemistry and ecology. There is 
a need to confront the pools of pollutants identified by different extractions with a wider palette of biological traits implicated in invertebrate fitness (e.g. life span, reproductive strategy). Hence, rapid progress demands an available multi-taxa multi-trait database. Then, it will be possible to uncorrelate specific pollutant impacts from those of other environmental factors.

\section{Acknowledgments}

Authors thank the technical staff of PESSAC research unit that participated in field samplings. The work was supported by an ANR08-CESA-012 grant for the RESACOR project. Authors also thank the colleagues participating to BETSI project (funded by the French Foundation for Biodiversity) for valuable discussion on trait-based approaches.

\section{Appendix. Supplementary material}

Supplementary data associated with this article can be found, in the online version, at doi:10.1016/j.envpol.2012.01.017.

\section{References}

Archaimbault, V., Usseglio-Polatera, P., Garric, J., Wasson, J.G., Babut, M., 2010. Assessing pollution of toxic sediment in streams using bio-ecological traits of benthic macroinvertebrates. Freshwater Biology 55, 1430-1446.

Baize, D., Tomasson, R., 2003. Modélisation empirique du transfert du cadmium et du zinc des sols vers les grains de blé tendre. Etude et Gestion des Sols 10, 219-239.

Bouché, M., 1972. Lombriciens de France. Ecologie et Systématique. Institut National de Recherches Agronomiques, Paris.

Bourennane, H., Dère, C., Lamy, I., Cornu, S., Baize, D., van Oort, F., King, D., 2006. Enhancing spatial estimates of metal pollutants in raw wastewater irrigated fields using a topsoil organic carbon map predicted from aerial photography. Science of the Total Environment 361, 229-248.

Brulle, F., Morgan, A.J., Cocquerelle, C., Vandenbulcke, F., 2010. Transcriptomic underpinning of toxicant-mediated physiological function alterations in three terrestrial invertebrate taxa: a review. Environmental Pollution 158, 2793-2808.

Capowiez, Y., Dittbrenner, N., Rault, M., Triebskorn, R., Hedde, M., Mazzia, C., 2010. Earthworm cast production as a new behavioural biomarker for toxicity testing. Environmental Pollution 158, 388-393.

Chevenet, F., Dolédec, S., Chessel, D., 1994. A fuzzy coding approach for the analysis of long-term ecological data. Freshwater Biology 31, 295-309.

COM179 final, 2002. Towards a Thematic Strategy for Soil Protection. Commission of the European Communities, Brussels, 35 p.

Crawford, C.S., 1976. Feeding-season production in the desert millipede Orthoporus ornatus (Girard) (Diplopoda). Oecologia 24, 265-276.

Curry, J.P., Schmidt, O., 2007. The feeding ecology of earthworms - a review. Pedobiologia 50, 463-477.

Dai, J., Becquer, T., Rouiller, J.H., Reversat, G., Bernhard-Reversat, F., Nahmani, J., Lavelle, P., 2004. Heavy metal accumulation by two earthworm species and its relationship to total and DTPA-extractable metals in soils. Soil Biology \& Biochemistry 36, 91-98.

Dangerfield, J.M., 1993. Ingestion of mineral soil/litter mixtures and faecal pellet production in the southern African millipede Alloporus uncinatus (Attems). Pedobiologia 37, 159-166.

Decaëns, T., Margerie, P., Aubert, M., Hedde, M., Bureau, F., 2008. Assembly rules within earthworm communities in North-Western France - a regional analysis. Applied Soil Ecology 39, 321-335.

Decaëns, T., 2010. Macroecological patterns in soil communities. Global Ecology and Biogeography 19, 287-302.

Demange, J.M., 1981. Les Milles-pattes. Myriapodes, Boubée, Paris.

Dère, C., Lamy, I., van Oort, F., Baize, D., Cornu, S., 2006. Reconstitution des apports en éléments traces métalliques et bilan de leur migration dans un Luvisol sableux soumis à 100 ans d'irrigation massive par des eaux usées brutes. Comptes Rendus Geosciences 338, 565-573.

Eeva, T., Sorvari, J., Koivunen, V., 2004. Effects of heavy metal pollution on red wood ant (Formica s. str.) populations. Environmental Pollution 132, 533-539.

Garnier, E., Cortez, J., Billès, G., Navas, M.-L., Roumet, C., Debussche, M., Laurent, G., Blanchard, A., Aubry, D., Bellmann, A., Neill, C., Toussaint, J.-P., 2004. Plant functional markers capture ecosystem properties during secondary succession. Ecology 85, 2630-2637.

Giller, P.S., 1996. The diversity of soil communities, the 'poor man's tropical rainforest'. Biodiversity and Conservation 5, 135-168.

Grelle, C., Fabre, M.C., Leprêtre, A., Descamps, M., 2000. Myriapod and isopod communities in soils contaminated by heavy metals in northern France. European Journal of Soil Science 51, 425-433.

Grzes, I.M., 2009. Ant species richness and evenness increase along a metal pollution gradient in the Boleslaw zinc smelter area. Pedobiologia 53, 65-73.
Haimi, J., Mätäsniemi, L., 2002. Soil decomposer animal community in heavy-metal contaminated coniferous forest with and without liming. European Journal of Soil Biology 38, 131-136.

Hobbelen, P.H.F., Van den Brink, P.J., Hobbelen, J.F., Van Gestel, C.A.M., 2006. Effects of heavy metals on the structure and functioning of detritivore communities in a contaminated floodplain area. Soil Biology \& Biochemistry 38, 1596-1607.

Hooda, P.S., 2010. Trace Elements in Soil. John Wiley and sons, Chippenham, UK.

Hopkins, S., 1991. A key to the woodlice of Britain and Ireland. Field Studies 7, 599-650.

ISO, 2008. ISO 17402. Soil quality - requirements and guidance for the selection and application of methods for the assessment of bioavailability of contaminants in soil and soil materials.

IUSS Working Group WRB, 2006. World reference base for soil resources. In: FAO (Ed.), World Soil Resources Reports No 103, second ed.. Rome.

Jeannel, R., 1941. Faune de France: Coléoptères Carabiques - Tome I. Lechevalier.

Jeannel, R., 1942. Faune de France: Coléoptères Carabiques - Tome II. Lechevalier.

Kaneko, N., 1999. Effect of millipede Parafontaria tonominea Attems (Diplopoda: Xystodesmidae) adults on soil biological activities: a microcosm experiment. Ecological Research 14, 271-279.

Kashem, M.A., Singh, B.R., Kondo, T., Imamul Huq, S.M., Kawai, S., 2007. Comparison of extractability of $\mathrm{Cd}, \mathrm{Cu}, \mathrm{Pb}$ and $\mathrm{Zn}$ with sequential extraction in contaminated and non-contaminated soils. International Journal Environmental Science \& Technology 4, 169-176.

Koponen, S., Koneva, G.G., 2005. Spiders along a pollution gradient (Araneae). In: Deltshev, C., Stoev, P. (Eds.), European Arachnology 2005. Acta Zoologica Bulgarica, pp. 131-136.

Lamy, I., van Oort, F., Dère, C., Baize, D., 2006. Use of major- and trace- element correlations to assess metal migration in sandy Luvisols irrigated with wastewater. European Journal of Soil Science 57, 731-740.

Lavelle, P., Spain, A.V., 2001. Soil Ecology. Kluwer Academic Publishers, Dordrecht.

Lavorel, S., Garnier, E., 2002. Predicting changes in community composition and ecosystem functioning from plant traits: revisiting the Holy Grail. Functional Ecology 16, 545-556.

Lock, K., Desender, K., Janssen, C.R., 2001. Effects of metal contamination on the activity and diversity of carabid beetles in an ancient $\mathrm{Pb}-\mathrm{Zn}$ mining area at Plombières (Belgium). Entomologia Experimentalis et Applicata 99, 355-360.

Lukkari, T., Taavitsainen, M., Väisänen, A., Haimi, J., 2004. Effects of heavy metals on earthworms along contamination gradients in organic rich soils. Ecotoxicology and Environmental Safety 59, 340-348.

Makkonen, M., Berg, M.P., van Hal, J.R., Callaghan, T.V., Press, M.C., Aerts, R., 2011. Traits explain the responses of a sub-arctic Collembola community to climate manipulation. Soil Biology and Biochemistry 43, 377-384.

McQuillan, P.B., Webb, W.R., 1994. Selective soil organic matter consumption by larvae of Adoryphorus couloni (Burmeister) (Coleoptera: Scarabaeidae). Australian Journal of Entomology 33, 49-50.

Mims, M.C., Olden, J.D., Shattuck, Z.R., Poff, N.L., 2010. Life history trait diversity of native freshwater fishes in North America. Ecology of Freshwater Fish 19, $390-400$.

Nahmani, J., Lavelle, P., 2002. Effects of heavy metal pollution on soil macrofauna in a grassland of Northern France. European Journal of Soil Biology 38, 297-300.

Paulian, R., 1941. Faune de France: Coléoptères Scarabeidés. Lechevalier.

Pizl, V., Schlaghamersky, J., Triska, J., 2009. The effects of polycyclic aromatic hydrocarbons and heavy metals on terrestrial annelids in urban soils. Pesquisa Agropecuaria Brasileira 44, 1050-1055.

Prüess, A., 1992. Vorsorgewerte und Prüfwerte für mobile und mobilisierbare potentiell ökotoxische Spurenelemente in Böden. Wendlingen, Stuttgart.

Ribera, I., Dolédec, S., Downie, I.S., Foster, G.N., 2001. Effect of land disturbance and stress on species traits of ground beetle assemblages. Ecology 82, 1112-1129.

Scheifler, R., Schwartz, C., Echevarria, G., de Vaufleury, A., Badot, P.-M., Morel, J.-L. 2003. "Nonavailable" soil cadmium is bioavailable to snails: evidence from isotopic dilution experiments. Environmental Science \& Technology 37, 81-86.

Skalski, T., Stone, D., Kramarz, P., Laskowski, R., 2010. Ground beetle community responses to heavy metal contamination. Baltic Journal of Coleopterology 10 , $1-12$.

Southwood, T.R.E., 1977. Habitat, Templet for Ecological Strategies - PresidentialAddress to British-Ecological-Society, 5 January 1977. Journal of Animal Ecology 46, 337-365.

Spurgeon, D.J., Hopkin, S.P., 1999. Seasonal variation in the abundance, biomass and biodiversity of earthworms in soils contaminated with metal emissions from a primary smelting works. Journal of Applied Ecology 36, 173-183.

Tajovsky, K., 1992. Feeding biology of the millipede Glomeris hexasticha (Glomeridae, Diplopoda). In: Innsbruck, N.m.V. (Ed.), 8th International Congress of Myriapodology, Innsbruck, Austria, July 15-20, 1990.

Tischer, S., 2008. Lumbricidae communities in soil monitoring sites differently managed and polluted with heavy metals. Polish Journal of Ecology 56, 635-646.

van Gestel, C.A.M., Koolhaas, J.E., Hamers, T., van Hoppe, M., van Roovert, M. Korsman, C., Reinecke, S.A., 2009. Effects of metal pollution on earthworm communities in a contaminated floodplain area: linking biomarker, community and functional responses. Environmental Pollution 157, 895-903.

van Gestel, C.A.M., 2008. Physico-chemical and biological parameters determine metal bioavailability in soils. Science of the Total Environment 406, 385-395.

van Oort, F., Jongmans, A.G., Lamy, I., Baize, D., Chevallier, P., 2008. Impacts of long-term waste-water irrigation on the development of sandy Luvisols: consequences for metal pollutant distributions. European Journal of Soil Science 59, 925-938.

Vijver, M.G., Vink, J.P.M., Jager, T., van Straalen, N.M., Wolterbeek, H.T., van Gestel, C.A.M., 2006. Kinetics of Zn and Cd accumulation in the isopod Porcellio 
scaber exposed to contaminated soil and/or food. Soil Biology and Biochemistry 38, 1554-1563.

Violle, C., Navas, M.-L., Vile, D., Kazakou, E., C, F., Hummel, I., Garnier, E., 2007. Let the concept of trait be functional. Oikos 116, 882-892.
Wolters, V., 2000. Invertebrate control of soil organic matter stability. Biology and Fertility of Soils 31, 1-19.

Wolters, V., 2001. Biodiversity of soil animals and its function. European Journal of Soil Biology 37, 221-227. 